\title{
A magyarországi készpénzkereslet változásának összehasonlító elemzése*
}

\author{
Végső Tamás
}

\begin{abstract}
A Magyarországon forgalomban lévő készpénzállomány elmúlt években tapasztalt erős növekedése látszólagos ellentmondásban van a fizetési szokások megváltozásával, emellett azt a benyomást keltheti, hogy a hazai fizetési rendszer fejlődése lemaradásban van Európa más államaihoz képest. Jelen tanulmány célja, hogy a magyarországi adatokat nemzetközi kontextusba helyezve valós képet adjon a készpénzhasználat hazai helyzetéröl, valamint a releváns szakirodalom felhasználásával bemutassa a készpénzkereslettel kapcsolatban világszerte megfigyelhetö trendeket. Fontos tanulság, hogy jellegét tekintve élesen elkülönül egymástól a tranzakciós és a megtakarítási célra irányuló kereslet - a készpénzállomány világszinten megfigyelhető bővüléséért elsősorban utóbbi a felelös. A Magyarországra jellemző növekedés európai összehasonlításban is magas ugyan, de figyelembe véve a kamatszintek és a GDP alakulását, nem mondható kirívónak. A nemzetközi tendenciák alapján hazánk számára középtávon elsősorban a bövülés lassitása lehet reális cél, a készpénzállomány nominális csökkenéséhez a tapasztalatok szerint számos tényező hosszú távú, együttes fennállása szükséges.
\end{abstract}

Journal of Economic Literature (JEL) kódok: D14, E41, E42, E58

Kulcsszavak: készpénzkereslet, GDP-arányos készpénzállomány, fizetési szokások, elektronikus fizetés, készpénzes megtakarítás, rejtett gazdaság, készpénzmentesség

\section{Bevezetés}

Napjainkban a világ szinte valamennyi országának lakói közvetlenül tapasztalhatják a fizetési szokások átalakulását. Magyarország sem tartozik a kivételek közé, elég csak a készpénzmentessé váló fesztiválokra gondolnunk, vagy éppen arra, hogy már a legtöbb utcai vásáron is fizethetünk kártyával, és olyan templomot is találhatunk, ahol a perselyt már kártyaolvasó terminál helyettesíti. Ezeket a jelenségeket a Magyar Nemzeti Bank (MNB 2019a) által kiadott Fizetési rendszer jelentés adatai is alátámasztják. Magyarországon 2017 és 2018 között darabszám és érték tekintetében is mintegy 25 százalékkal nőttek a bankkártyás fizetések, napjainkban

\footnotetext{
* A jelen kiadványban megjelenő írások a szerzők nézeteit tartalmazzák, ami nem feltétlenül egyezik a Magyar Nemzeti Bank hivatalos álláspontjával.

Végső Tamás a Magyar Nemzeti Bank készpénzpolitikai szakértője. E-mail:vegsot@mnb.hu A magyar nyelvű kézirat első változata 2019. szeptember 16-án érkezett szerkesztőségünkbe. DOI: http://doi.org/10.25201/HSZ.19.1.90118
} 
pedig a tranzakciók több mint háromnegyede olyan üzletekben történik, ahol van lehetőség elektronikusan fizetni. Az elmúlt években robbanásszerű volt az „érintéses” kártyák elterjedése, valamint a különféle mobilfizetési megoldások is egyre szélesebb körben elérhetőek.

A köztudatba Svédország példáján keresztül bekerült a „készpénzmentes állam” fogalma, de többek között Hollandiáról és Nagy-Britanniáról is gyakran olvashatunk az elektronikus fizetések széleskörű alkalmazásának éllovasaiként. Az azonnali, készpénzmentes fizetési megoldások folyamatos fejlődésen mennek keresztül, sebességük és megbízhatóságuk évről évre nő, emellett pedig egyre nagyobb figyelem irányul a fizetések terén is alkalmazható blockchain vagy „distributed ledger" (DLT) technológiák felé mind a vállalatok, mind pedig a jegybankok részéről (lásd például Bech et al. 2017, FIS 2018). Ezzel egyidőben azonban szintén általános nemzetközi jelenség az egyes országok készpénzállományának bővülése is, ami látszólag ellentmond a fizetési rendszerek fejlődésének. Az MNB adatai szerint a forgalomban lévő forint bankjegyek és érmék értéke 2012 óta folyamatosan, átlagosan évi 10 százalékot meghaladó mértékben növekszik, 2019 decemberére pedig átlépte a 6500 milliárd forintot is. 2018 folyamán különösen hangsúlyos volt a készpénz iránti kereslet növekedése: egy naptári év alatt több mint 850 milliárd forint áramlott ki a jegybankból. Mindez azonban nem csupán hazánkra jellemző. A külföldi jegybankok adatait megvizsgálva megállapítható, hogy az elmúlt évtizedben a világ szinte valamennyi állama hasonló jelenségekkel volt kénytelen szembesülni.

Mi tehát az igazság a készpénzzel kapcsolatban, és mire számíthatunk az elkövetkező években? Jelen tanulmány elsőként röviden ismerteti a Magyarországon forgalomban lévő készpénzállomány elmúlt években tapasztalt növekedését, bemutatja és rendszerezi a készpénzkereslet témakörében a nemzetközi szakirodalomban megjelent releváns kutatásokat, majd ezen információk tükrében tesz kísérletet a hazai folyamatok értelmezésére, és részletesebben taglal néhány tanulságos külföldi példát. Ezt követően - elsősorban szintén a nemzetközi szakirodalomra támaszkodva - foglalkozik a készpénz jövőjével és a készpénzmentes gazdaság lehetőségeivel is.

\section{A hazai készpénzkereslet alakulása}

Az MNB adatai alapján a Magyarországon forgalomban lévő készpénzállomány 2012 óta értékét tekintve évente átlagosan 14 százalékkal nőtt, 2019 decemberére pedig meghaladta a 6500 milliárd forintot is. Ez a tény éles ellentmondásban áll a közvélekedéssel, mely szerint a folyamatosan fejlődő elektronikus megoldásoknak hála, a készpénz mint fizetőeszköz napjainkban már elavultnak, meghaladottnak tekinthető.

Az elmúlt évtizedben Magyarországon egyszerre zajlott mind a forgalomban lévő készpénzállomány ugrásszerű növekedése, mind pedig az elektronikus fizetési 
megoldások gyors térnyerése. A vásárlási tranzakciók egyes fizetési módok közötti megoszlásáról 2015-től kezdve pontos képet ad az online pénztárgépek alkalmazására kötelezett üzletek ${ }^{1}$ adatait tartalmazó OPG-adatbázis, ennél hosszabb időtávot vizsgálva azonban célszerü egyéb becslésekre támaszkodni. Egy lehetséges módszer - melyet például Khiaonarong - Humphrey (2019) is alkalmaz - az éves lakossági fogyasztás értékének és az elektronikusan fizetett vásárlások éves összegének az 1. ábrán látható módon történő összevetése. Az ábráról leolvasható, hogy míg 2012 óta az elektronikus vásárlások értéke több mint háromszorosára nőtt, az éves fogyasztás fennmaradó része - mely a készpénzes vásárlások jó közelítésének tekinthető - lényegében stagnált. Mindez arra utal, hogy a forgalomban lévő készpénzállomány növekedése nem a lakossági fizetési szokások megváltozásának tudható be.

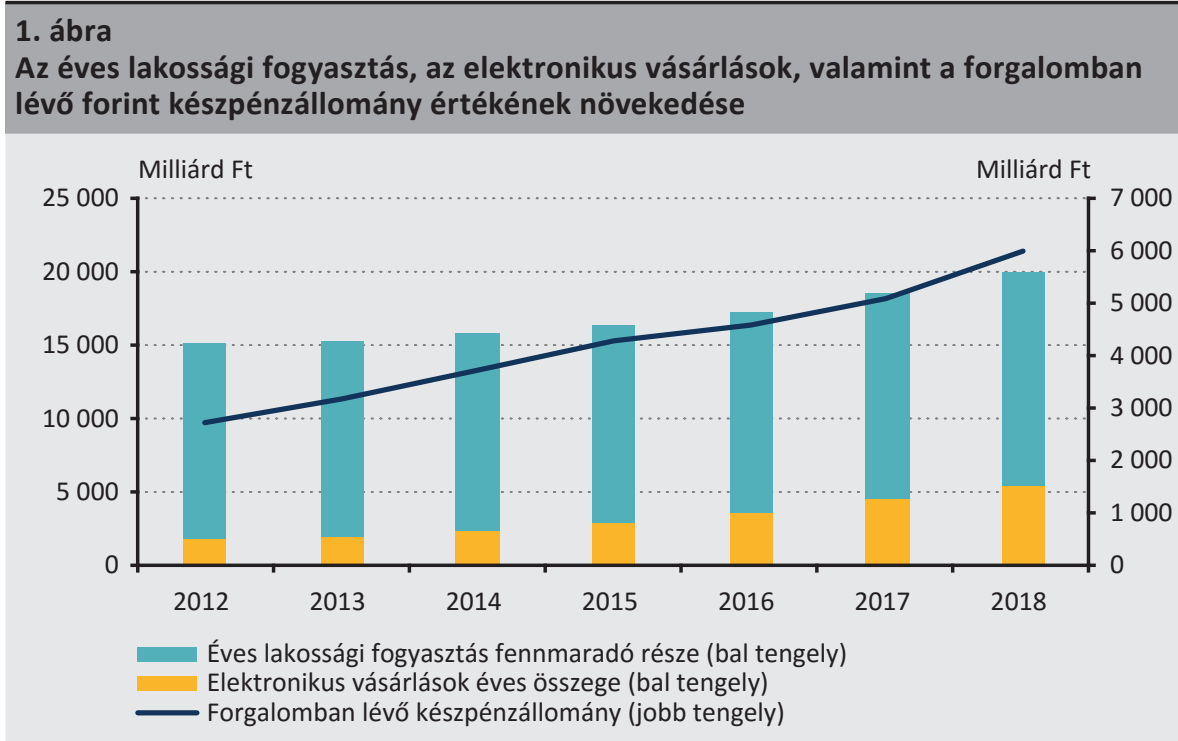

Forrás: $K S H, M N B$

Mindemellett azonban fontos kihangsúlyozni, hogy a készpénzmentes fizetési megoldások használatának növekedése ellenére hazánkban továbbra is a készpénz a legnagyobb számban és értékben használt fizetési eszköz. Az MNB (2019a) által kiadott Fizetési rendszer jelentés szerint 2017-ben az online pénztárgépeken végrehajtott vásárlások darabszám szerint 85 százaléka, érték szerint 68 százaléka készpénzben történt. 2015 és 2017 között a regisztrált készpénzes tranzakciók aránya több mint 5 százalékkal, összesített darabszáma viszont mindössze 1 százalékkal csökkent.

${ }^{1}$ A Nemzeti Adó- és Vámhivatal által online pénztárgép használatára kötelezett üzletek elsősorban a kiskereskedelmi szektort reprezentálják. 
Sokatmondó adat, hogy 2018-as, önbevalláson alapuló kutatási eredmények szerint a magyar lakosság 46 százaléka szinte kizárólag készpénzzel fizeti rendszeres vásárlásait, 28 százalékuk a készpénzt és a kártyás fizetést párhuzamosan veszi igénybe, a készpénzmentes megoldásokat pedig csak 26 százalék preferálja (Végső et al. 2018).

A bővülő készpénzigény és az ezzel ellentétes irányba változó fogyasztói szokások közötti látszólagos ellentmondás megértéséhez segítséget nyújt annak ismerete, hogy a készpénzállomány elmúlt években tapasztalt erős növekedése főként a legnagyobb címletű, 20000 forintos bankjegyeket érintette. Az ebból a címletből forgalomban lévő mennyiség 2012 és 2019 között közel háromszorosára emelkedett, míg a 10000 forintosok esetén csak kb. 70 százalékos, a kisebb címletek esetén pedig 25-40 százalékos növekedés volt megfigyelhető (az érték szerinti megoszlást az egyes címletek között a 2. ábra mutatja). Bár erre vonatkozóan módszertanilag megalapozott, számszerű becslés hazánkban még nem készült, joggal feltételezhető, hogy a nagy címletű bankjegyek számottevő része nem tranzakciós, hanem közép- vagy hosszú távú megtakarítási célokat szolgál. Ebből következően a készpénzállomány ezen részének növekedése független az elektronikus fizetési megoldások elterjedésétől, más tényezők befolyásolják (például a tartósan alacsony kamatkörnyezet vagy a gazdasági bizonytalanságtól való félelem, bővebben lásd 3.2. és 4.3. fejezetek).

A nagy címletű bankjegyek iránt megnövekedett kereslet különböző mértékben, számos más országban is megfigyelhető volt, így a jelenség a jegybankok érdeklődését is felkeltette. Flannigan - Parsons (2018) például nagy-britanniai, ausztrál és kanadai adatokat vizsgálva szignifikáns korrelációt mutatott ki az ingatlanárak, illetve az ingatlanfelújítások költségei és a nagy címletű bankjegyek forgalma között, az egyéb magyarázó tényezők között pedig a pénzügyi instabilitástól való félelem is szerepelt.

\section{2. ábra \\ A forgalomban lévő forint készpénzállomány értékének címletek szerinti megoszlása 2006 és 2018 között}

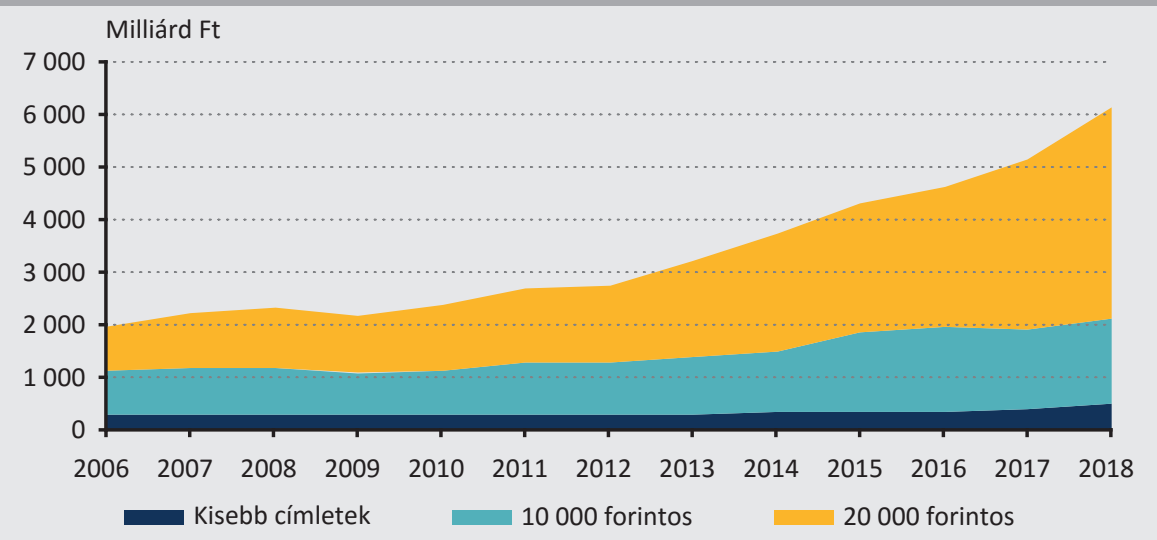

Forrás: $M N B$ 
A készpénz iránti hazai kereslet megtakarítási motivációit az is alátámasztja, hogy a KSH nemzeti számlákra vonatkozó adatai szerint a magyar háztartások készpénzben tartott vagyona 2013 és 2018 között közel megduplázódott, 2537 milliárd forintról 4788 milliárd forintra nőtt. A megtakarítási szokások megváltozását egyéb, a készpénzkeresletet befolyásoló tényezőkkel együtt részletesebben a 4.3 fejezet tárgyalja.

\section{Mire kell nekünk a készpénz?}

A készpénz helyzetének megértéséhez - akár hazai, akár nemzetközi viszonylatban vizsgáljuk - nem elég csupán általában vett készpénzkeresletről beszélnünk. A világ szinte valamennyi országában jól elválasztható a tranzakciós, illetve a megtakarítási célú készpénzigény, melyeket egyidejüleg akár ellentétes irányú mozgások is jellemezhetnek. Emellett - bár átfedésben vannak az előző két kategóriával - külön említést érdemelnek az egy adott ország valutája iránt külföldről érkező kereslet, valamint a rejtett gazdaság készpénzhasználata is, mely illegális tevékenységekhez kapcsolódik (például adóelkerülés, feketemunka, csempészet), és jellegéből adódóan különösen nehezen becsülhető meg.

\subsection{Tranzakciós célú készpénzkereslet}

Történelmileg a készpénz létrejöttének elsődleges célja a különféle áruk és szolgáltatások cseréjének megkönnyítése volt. A bankjegyek és érmék ezen szerepüket még napjainkban is őrzik, a XX. század második felétől kezdve azonban mellettük számos egyéb megoldás is megjelent e téren, a csekkek kibocsátásától kezdve a bankszámlák közötti átutaláson és a kártyás fizetésen keresztül egészen a mobiltelefonok által nyújtott megoldásokig.

A készpénzmentes fizetések terjedése értelemszerűen csökkenti a készpénz részarányát a tranzakciós forgalmon belül, ám a világ legnépszerübb és legszélesebb körben alkalmazott fizetőeszközeinek továbbra is a bankjegyek és érmék tekinthetők (G4S 2018). A tranzakciós célú készpénzkereslet, illetve változásai a készpénz egyéb felhasználási területeihez képest viszonylag könnyen megbecsülhetők, akár a hazai online pénztárgép adatbázishoz hasonló kereskedelmi adatszolgáltatások, akár reprezentatív, jellemzően fizetési naplót is tartalmazó lakossági felmérések alapján. Ilyen kutatásokat az Európai Központi Bank (Esselink - Hernández 2017), a Fed (Greene - Stavins 2018), valamit többek között a svájci (Schweizerische Nationalbank 2018), a német (Deutsche Bundesbank 2018), a holland (Jonker et al. 2018), a kanadai (Fung et al. 2015), a japán (Fujiki - Tanaka 2018) és az ausztrál (Doyle et al. 2017) jegybank is rendszeresen publikál, de a témában magyar adatokon alapuló friss elemzések is elérhetőek (Végső et al. 2018 és Ilyés - Varga 2015).

A hivatkozott kutatások közös eleme, hogy - bár a készpénz mint fizetési eszköz népszerűsége sok helyen, például hazánkban is tartósnak mondható - jellemzően 
a tranzakciós készpénzhasználat relatív csökkenéséről számolnak be, ami azonban a vonatkozó országokban nem jár együtt a készpénz iránti kereslet csökkenésével. Fujiki - Tanaka (2018) becslése szerint például 2017-ben Japánban az elektronikus fizetések által kiszorított tranzakciós készpénzigény mindössze a teljes forgalmi állomány 0,4 százalékát tette ki. A közgazdászok körében általános egyetértés mutatkozik azzal kapcsolatban, hogy a készpénz keresletét napjainkban elsősorban a megtakarítási igények határozzák meg (Assenmacher et al. 2019; Bech et al. 2018; Flannigan - Parsons 2018; Jobst - Stix 2017).

A különféle szociodemográfiai tényezők egyértelműen befolyásolják a lakosság tranzakciós célú készpénzhasználatát, a hatások konkrét jellege és iránya azonban nemzetenként igen eltérő lehet. Szemléletes példa a vonatkozó kérdőíves felmérések eredményét tekintve, hogy hazánkban a fizetési módok (elsősorban készpénz és bankkártya) közötti preferenciákra vonatkozóan az iskolai végzettség és a háztartás jövedelme igen erős magyarázó erővel bír, míg az életkor önmagában kevéssé mutat korrelációt a fizetési szokásokkal (Végső et al. 2018). Ezzel szemben Franciaországban (Politronacci et al. 2018) ugyanezen kérdést vizsgálva a végzettség és a jövedelem bizonyul inszignifikánsnak a készpénzhasználat szempontjából, míg az életkor igen erősen összefügg a fizetés módjával.

Általánosabb érvényűnek tűnik azonban Sisak (2011) és Arango-Arango Suárez-Ariza (2019) megállapítása, mely szerint nemzetközi adatok alapján az országok fizetési rendszereinek fejlettségét kifejező változók erős negatív irányú összefüggést mutatnak a tranzakciós célú készpénzkereslettel. Szintén széles körben igazolt, hogy az egyes fizetési módok szubjektív megítélése (Khan et al. 2015), valamint az azokhoz kapcsolódó költségek (Arango et al. 2015; Stavins 2018) is számottevően befolyásolják a lakosság fizetési szokásait, ezen keresztül pedig a tranzakciós készpénzkeresletet is. Ezen állításokat hazai kérdőíves felmérések tapasztalatai is megerősítik (pl. Végső et al. 2018). További érdekes eredményeket tartalmaz a kis címletű készpénz iránti keresletről Bech et al. (2018) tanulmánya, mely szerint a lakosság átlagéletkora, valamint az egy főre jutó GDP is szignifikáns mértékben befolyásolja azt (előbbi pozitív, utóbbi negatív irányban).

\subsection{Megtakarítási célú készpénzkereslet}

A tranzakciós célú készpénzkeresletet vizsgáló, fentebb hivatkozott kutatások többsége kísérletet tesz a megtakarítási célú készpénztartás felmérésére is. Mivel azonban a lakosság a készpénz fontos előnyének tartja az anonimitást (Végső et al. 2018), az önbevallásos módszer csak mérsékelten alkalmas a jelenség valódi mértékének meghatározására.

Valamivel pontosabb képet adhatnak az ökonometriai eszközökkel végzett elemzések. Anderson (1977) például a bankjegyek élettartamát figyelembe vevő módszert dolgozott ki, mely azon a megfigyelésen alapul, hogy a megtakarítási céllal tartott 
papírpénzek lassabban használódnak el, mint azok a társaik, melyek nap mint nap részt vesznek a készpénzforgalomban. Sumner (1990) ezzel szemben a bankjegyek iránti kereslet szezonalitásán keresztül határozza meg a készpénzes megtakarítások volumenét, mivel álláspontja szerint az ilyen jellegű kereslet nem mutat számottevő hullámzást adott hónapon vagy éven belül, míg a tranzakciós készpénzhasználatban például hónapok elején és nagyobb ünnepekkor is szignifikáns mértékú ideiglenes növekedés figyelhető meg. Bartzsch et al. (2011a, 2011b) többek között a fent említett módszereket is alkalmazó elemzésének megállapítása szerint a 2010-es évek elején Németországban kibocsátott euro bankjegyeknek mindössze 10-15 százaléka szolgált tranzakciós célokat. További 10-30 százalékra becsülhető a belföldön, megtakarításként tartott készpénz aránya, míg a fennmaradó 60-70 százalék külföldre áramlik, feltehetően szintén főként megtakarítási célokból. Franciaországra vonatkozóan Politronacci et al. (2017) is hasonló arányokat állapít meg a tranzakciós és megtakarítási célú készpénzkereslet mértékét illetően, Assenmacher et al. (2019) a svájci adatokon végzett elemzése alapján pedig a frank bankjegyek is ehhez közeli, 55-70 százalékos arányban szolgálnak biztonsági tartalékként, ez az arány azonban a legnagyobb, 1000 frankos címlet² esetén a 90 százalékot is meghaladhatja.

Fujiki - Nakashima (2019) szerint a japán jen bankjegyek állományának valamivel kisebb részéért, 40-45 százalékáért felelnek a készpénzes formában lévő megtakarítások, míg Judson (2017) megállapítása alapján az amerikai dollár papírpénzeinek már csupán a külföldi kézben lévő megtakarításai is 70 százalékot tehetnek ki. A külföldi kereslet az amerikai dollár esetében becsültnél valamivel kisebb, de továbbra is szignifikáns szerepet játszhat többek között az euro (Lalouette - Esselink 2018), a svájci frank (Assenmacher et al. 2019), az angol font és a kanadai dollár (Flannigan - Parsons 2018) forgalmában is. Érdemes megemlíteni, hogy az egyes valuták iránti külföldi kereslet nem csak megtakarítási célokat szolgálhat. Ecuadorban például 2000 óta hivatalos fizetőeszköz az amerikai dollár, 2002 óta pedig egyoldalú döntésük alapján Koszovó és Montenegró is euro bankjegyeket és érméket használ.

Az elmúlt években a fejlett világban tapasztalt drasztikus készpénzmennyiség-növekedés, valamint ezen belül is a készpénzes megtakarítások gyarapodásának magyarázatára tesz kísérletet Jobst - Stix (2017). A szerzők 70 országra kiterjedő adatelemzésük során megállapítják, hogy a GDP-arányos készpénzállomány mutató legjelentősebb emelkedései az 1929-1933-as gazdasági válsághoz, a II. világháborúhoz, valamint a 2007-2009-es pénzügyi válsághoz kapcsolhatók, mind az USA, mind pedig Európa esetében. A szerzők ehhez kapcsolódó hipotézise szerint a jelenleg világszerte tapasztalható növekvő megtakarítási készpénzigény nem magyarázható kizárólag az alacsony kamatkörnyezettel vagy a rejtett gazdaság szerepével, ahhoz szükség van a gazdasági-társadalmi válsághelyzet által keltett bizonytalanságra is,

\footnotetext{
${ }^{2}$ Az 1000 frankos bankjegy értéke 2019. decemberi árfolyamon körülbelül 300000 forint.
} 
amely hosszú éveken keresztül befolyásolhatja a lakosság, a vállalati és a pénzügyi szektor gondolkodását is.

A kamatkörnyezet hatását a nagy címletű bankjegyek iránti (megtakarítási célú) keresletre Sisak (2011), valamint Bech et al. (2018) elemzése is megerősíti, utóbbi szerzők azonban meglepő módon az általuk vizsgált országok esetén nem tudnak szignifikáns korrelációt kimutatni a makrogazdasági bizonytalanságot leíró változók és a nagy címletek forgalma között.

\subsection{Készpénz a rejtett gazdaságban}

A készpénzzel szemben gyakran megfogalmazott kritika, hogy az általa nyújtott likviditás és anonimitás kiváló táptalajt biztosít a rejtett gazdaság különféle illegális tevékenységei számára. Ezt a nézetet vallja az IMF és a Fed korábbi közgazdásza, a Harvard professzora, Kenneth Rogoff (2016) is. The Curse of Cash címü könyvének egyik fő állítása, hogy mivel a készpénz jelenleg fontos szerepet játszik például a korrupció, a csempészet és a terrorizmus finanszírozásában, megszüntetése komoly segítséget nyújtana felszámolásukban.

Ezen állítás igazolását vagy cáfolását, valamint a fenti célok érdekében használt készpénz mértékének meghatározását azonban rendkívül nehézzé teszi, hogy egyrészt illegalitása miatt már maga a rejtett gazdaság kiterjedése is csak pontatlanul, indirekt módokon becsülhető meg, másrészt az adatelemzések során az illegális tevékenységekből származó készpénz csak nehezen választható el a legális tranzakcióktól, illetve a legálisan tartott megtakarításoktól. Ennek megfelelően a vonatkozó nemzetközi szakirodalom is számos, egymásnak gyakran ellentmondó kutatást tartalmaz. Wright et al. (2017) több USA-beli állam adatait felhasználva arra a következtetésre jut, hogy a szociális juttatások elektronikus alapúvá tétele számottevően csökkentette a betörések, a lopások és az utcai bünözés mértékét is, Immordino - Russo (2018) pedig az adóelkerülés (ezalatt elsősorban az áfa-csalásokat értve) és a bankkártyahasználat mértéke között mutat ki szignifikáns korrelációt. Fontos azonban, hogy a szerzők szerint a kártyák fizetési használata összefügg az adóelkerülés csökkenésével, míg az ATM-ből történő kártyás készpénzfelvételek ezzel ellentétes irányú kapcsolatot mutatnak. Seitz et al. (2018) az eurozóna készpénzforgalmát vizsgálva megállapítja, hogy a rejtett gazdaság becsült mérete nincs számottevő hatással a készpénz iránti keresletre. A legnagyobb címletek iránti igény nem mutat statisztikailag szignifikáns korrelációt az illegális tevékenységekkel, és a közepes címletek esetén is csak néhány ország adataiban figyelhető meg a vártnál jóval gyengébb összefüggés. A német jegybank (Deutsche Bundesbank 2019) regressziós elemzése bizonyos esetekben szignifikáns pozitív korrelációt mutat a munkanélküliség, valamint a drogokkal kapcsolatos búncselekmények száma és a helyi készpénzigény között, a számos bizonytalansági tényező miatt azonban a szerzők szerint az eredmények csak korlátozottan alkalmasak következtetések levonására a készpénz és a rejtett gazdaság kapcsolatát illetően. 


\section{Hazai adatok nemzetközi összehasonlítása}

A hazai folyamatok helyes értelmezéséhez feltétlenül szükséges a régiós, európai és világszintű trendek ismerete is. A készpénzkiáramlás és a forgalomban lévő készpénzmennyiségek számszerű összehasonlításához kézenfekvőnek tűnhet a nominális értékek - illetve az árfolyam-ingadozások kiküszöbölése érdekében százalékos megváltozásaik - használata, a gyakorlatban azonban jóval elterjedtebb az úgynevezett GDP-arányos készpénzállomány mutató alkalmazása. Ez a mutatószám az adott ország nemzeti össztermékéhez viszonyítva adja meg a forgalomban lévő bankjegyek és érmék értékét. Bevezetése azon a mögöttes logikán alapul, hogy állandó lakossági és vállalati fizetési és megtakarítási szokások mellett is változhat egy ország gazdaságának készpénzigénye, amennyiben a gazdaság teljesítőképessége nő vagy csökken. További előnye az összehasonlíthatóság szempontjából, hogy mentes az árfolyamváltozások torzító hatásaitól is.

A fejezet további része ennek megfelelően a nominális állományi adatokból levonható következéseket csak érintőlegesen tárgyalja, és nagyobb hangsúlyt fektet a GDP-arányos készpénzállományi mutatókra, illetve a készpénz iránti keresletet potenciálisan befolyásoló tényezőkre. Emellett néhány, a készpénz jelenlegi és jövőbeli helyzete szempontjából tanulságos külföldi példát részletesebben is ismertetünk.

\subsection{Nominális készpénzállomány}

Az eurozóna, valamint a közép-európai régió jegybankjainak nominális adatait megvizsgálva megállapítható, hogy a készpénzkereslet utóbbi években lezajlott erős növekedése nem kizárólag hazánkra jellemző (3. ábra). A gazdasági válság kezdetét jelentő 2008-as évet bázisul véve megfigyelhető, hogy Romániában, valamint 2016ig Lengyelországban is Magyarországhoz hasonló mértékben növekedett a forgalomban lévő készpénzállomány. Csehországban és az eurozónában is folyamatos, bár nominálisan jóval kisebb ütemű emelkedés volt tapasztalható. Fontos azonban kihangsúlyozni, hogy a készpénzállomány nominális megváltozásának vizsgálata az adott országra jellemző gazdasági mutatók (pl. infláció, jövedelemváltozás, kamatszint) figyelembevétele nélkül csekély relevanciával bír. 


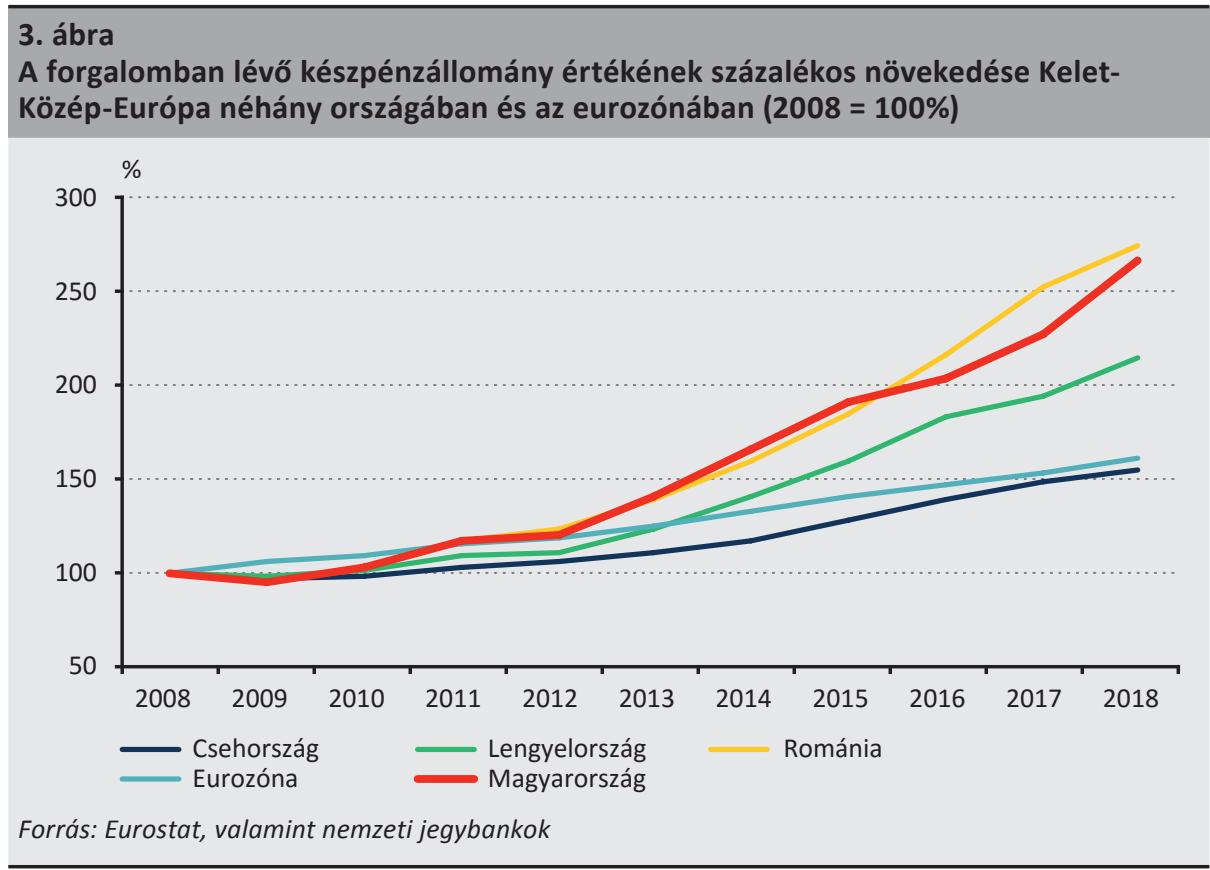

A régióban nem jellemző, hogy - Magyarországhoz hasonlóan - a legnagyobb címletű bankjegy adná a forgalomban lévő készpénzmennyiség túlnyomó részét. Az elmúlt években szinte mindenhol megfigyelhető volt a címletstruktúra bizonyos mértékű eltolódása a nagyobb értékű bankjegyek felé, a kereslet bővülése azonban jellemzően a második, esetleg harmadik legtöbbet érő címleteket érintette (4. ábra). A helyzetet némileg árnyalja, hogy a vizsgált országok, valamint az eurozóna ${ }^{3}$ legnagyobb bankjegycímleteinek vásárlóerőparitással korrigált értéke ${ }^{4}$ kivétel nélkül nagyobb (1,5-2,5-szöröse) a magyar 20000 forintos bankjegyének, továbbá ezen nagy értékú bankjegyek jellemzően nem, vagy csak ritkán szerepelnek az ATMek kínálatában. Így joggal feltételezhető, hogy ezen esetekben a második, illetve akár a harmadik legnagyobb értékú címlet esetén is szignifikáns lehet a megtakarítási célú igény. Ezen adatokból tehát nem jelenthető ki egyértelmúen, hogy a környező országokban a forgalomban lévő készpénzállomány bővülésére arányaiban lényegesen nagyobb hatással volna a tranzakciós célú kereslet, mint hazánkban.

\footnotetext{
${ }^{3}$ Az eurozóna esetén a 200 eurós bankjegyet tekintettük a legnagyobb értékú címletnek, mivel az 500 eurós bankjegy - bár továbbra is törvényes fizetőeszköznek minősül - 2019. áprilisa óta nem kerül további kibocsátásra, forgalomban lévő mennyisége pedig az elmúlt években jó közelítéssel stagnált.

${ }^{4}$ A PPP konverziós értékek forrása az IMF által összeállított World Economic Outlook (October 2019) adatbázis.
} 


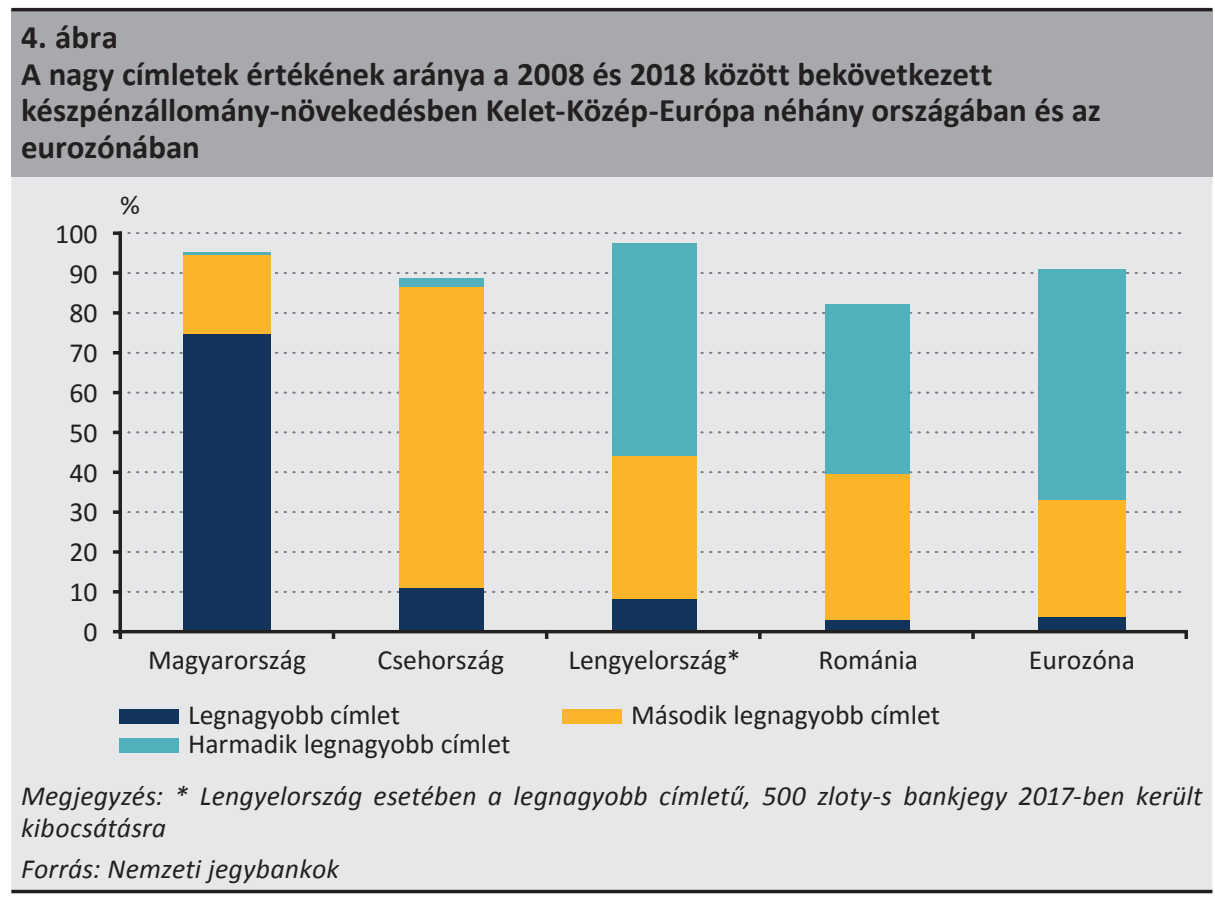

Sokatmondó adat a készpénz globális helyzetéről, hogy a jegybankok adatai szerint a fejlett világban mindössze két olyan ország található, ahol az elmúlt években tartósan bekövetkezett a forgalomban lévő készpénzmennyiség nominális csökkenése: Norvégia, valamint Svédország. Előbbinél csak 2015 óta figyelhető meg visszaesés, míg utóbbi állam esetén több mint 10 éve zajlik a forgalomban lévő bankjegyek és érmék visszaáramlása, a trend azonban 2018-ban nagy meglepetésre megfordult. A Svédországban forgalomban lévő készpénzállomány értéke az év folyamán 7,2 százalékkal nőtt. A korábbi csökkenés lehetséges okai részletesebben a 4.4.1. alfejezetben olvashatók.

\subsection{GDP-arányos készpénzállomány}

A mutatószámra vonatkozó hazai adatokat tekintve elmondható, hogy 2012 és 2018 között - a nominális értékhez hasonlóan - Magyarországon a GDP-arányos készpénzállomány is számottevően, 6 év alatt több mint másfélszeresére nőtt (5. ábra). 


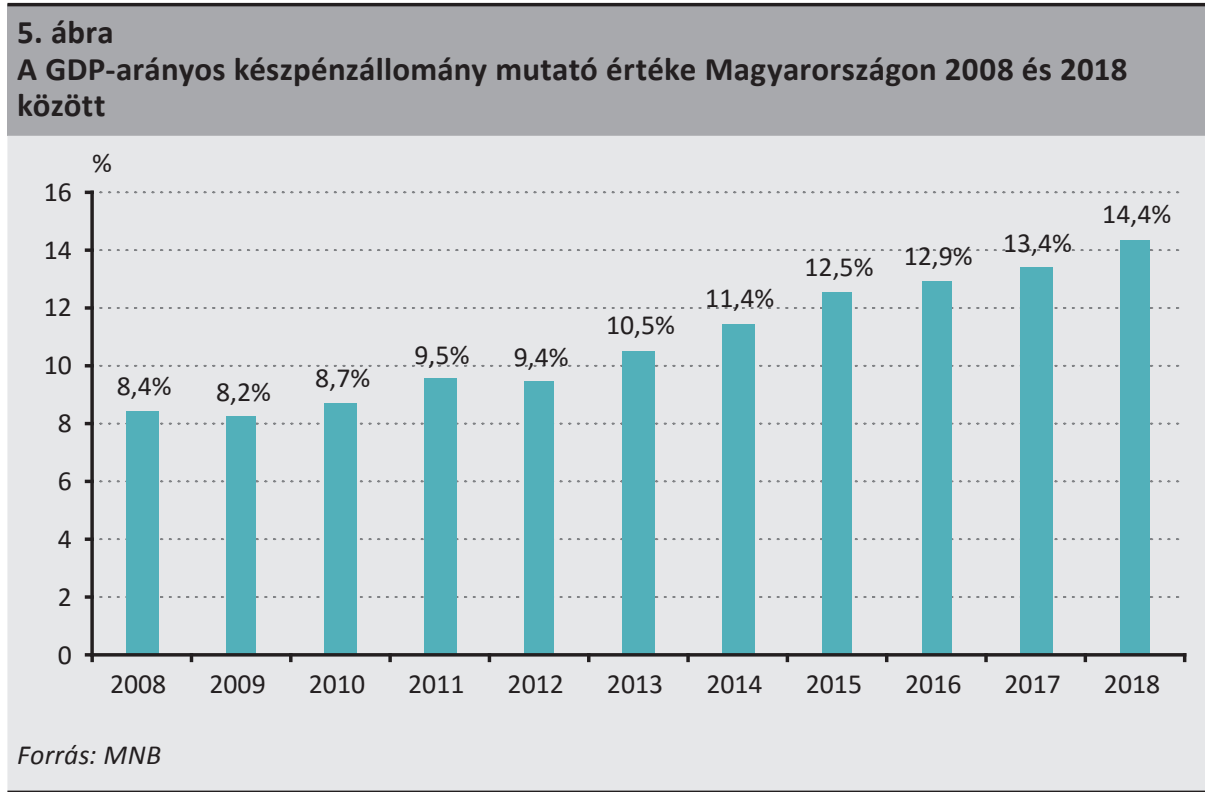

A 2018-as hazai értékeket az eurozónával ${ }^{5}$ és a saját valutával rendelkező EU-tagállamokkal (valamint Svájccal) összevetve hasonló következtetésre juthatunk, mint a nominális növekedést vizsgálva. A magyar GDP-arányos készpénzállomány európai összehasonlításban magasnak mondható, a különbség azonban sem a környező országokhoz, sem az eurozónához viszonyítva nem kirívó mértékű (6. ábra). A világ egyik legnagyobb készpénzlogisztikai szolgáltatója, a brit G4S (2018) cégcsoport által kiadott World Cash Report szerint a világszinten összesített GDP-arányos készpénzmennyiség mutató 2011 óta folyamatosan emelkedik, jelenlegi becsült értéke megközelítőleg 10 százalék. Az Európára vonatkozó összesített érték ennél csak kevéssel alacsonyabb, 9 százalék körüli, és szintén folyamatos növekedés jellemzi.

Érdemes megfigyelni, hogy a mutató eurozónára vonatkozó értéke 2 százalékponttal magasabb a romániai adatnál, valamint - az összehasonlítást más földrészekre is kiterjesztve - jelentősen meghaladja a Törökországra jellemző értéket, és csak 0,6 százalékkal marad el az indiai adattól. A fentiek jól példázzák, hogy a GDP-arányos készpénzállomány sem minden esetben alkalmas arra, hogy rajta keresztül összehasonlítsuk különböző országok fizetési infrastruktúrájának fejlettségét, valamint a készpénzhasználat mértékét, illetve a lakosság és a vállalatok készpénzhez fúződő viszonyát. Ennek oka alapvetően a fejlett és fejlődő országok esetén mind napjainkban, mind pedig historikusan szignifikánsan eltérő jegybanki alapkamat szint, valamint bizonyos esetekben az adott ország valutája iránti külföldi kereslet is számottevő lehet. Az előb-

${ }^{5}$ A készpénz forgalomba bocsátásának helyszíne alapján a GDP-arányos készpénzállomány az eurozóna egyes tagállamaira külön-külön is megbecsülhető, ezen becslések azonban az országok közötti nagymértékú készpénzáramlás miatt igen pontatlanok, megbízható következtetések levonására csak korlátozottan alkalmazhatók, ezért jelen elemzés során nem vesszük figyelembe őket. 
bieknél jóval kisebb mértékben ugyan, de szerepet játszhatnak kulturális jellegü, a lakosság fogyasztási és megtakarítási szokásait befolyásoló tényezők is.

\section{6. ábra \\ A GDP-arányos készpénzállomány mutató értéke 2008-ban és 2018-ban \\ Magyarországon, valamint Európa, illetve a világ néhány egyéb államában}

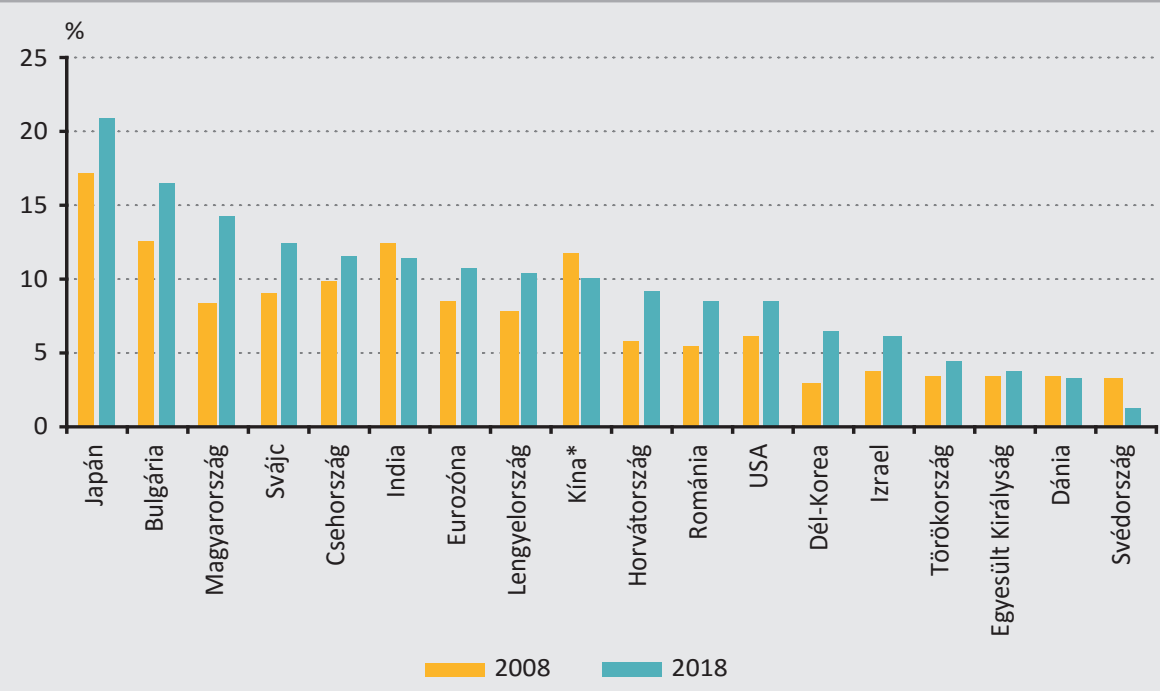

Megjegyzés: * Kína esetében a tanulmány írása idején elérhető legfrissebb adat 2017-es

Forrás: BIS, valamint nemzeti jegybankok

Khiaonarong - Humphrey (2019) további kritikát fogalmaz meg a GDP-arányos készpénzállomány használatával szemben. Álláspontjuk szerint a mutató akkor hordozná valóban a neki tulajdonított jelentést, ha nem a teljes GDP-t, hanem csak annak fogyasztásból eredő komponenseit vennénk figyelembe, mivel ez az a terület, ahol a készpénz valóban felhasználásra kerülhet. Javaslatuk alkalmazását azonban megnehezíti, hogy az ehhez szükséges adatok számos, jelen tanulmányban vizsgált ország esetén nem érhetők el. A szerzők emellett korlátozottan veszik tekintetbe, hogy a készpénzállomány jelentős része feltehetően nem fogyasztási, hanem megtakarítási célokat szolgál.

\subsection{A készpénzállomány hazai növekedését magyarázó tényezők}

Amint az korábban bemutatásra került, a hazánkban forgalomban lévő készpénzállomány növekedése szinte kizárólag a nagy címletek iránti kereslet bővülésének köszönhető, ez a jelenség pedig különböző mértékben, de a környező országok egy részében is megfigyelhető.

Mivel a nagy címletek elsősorban feltehetően megtakarítási célokat szolgálnak, arra következtethetünk, hogy a lakossági megtakarítási szokások változása szignifikáns hatással lehet a készpénzigényre. A készpénztartás alternatívaköltségei nagyban 
függnek a jegybanki alapkamattól, így a kamatszint alakulása magyarázatot adhat az egyes országok készpénzállományának a 6. ábrán is megfigyelhető eltérő alakulására. Ez különösen szembetűnő Japán esetében, ahol az 1990-es évek közepe óta 0 közeli alapkamat világviszonylatban is kiugró készpénz/GDP aránnyal párosul, de Törökország és akár India esetében is igaz, hogy a nemzetközi összehasonlításban magasnak számító kamatok a fejlett világ országaival összehasonlítva alacsonyabb GDP-arányos készpénzállományt eredményeznek. Bár a 2012 óta tapasztalható növekedésre hazánkban is szignifikáns hatással van az alacsony kamatszint (lásd például Lybek - Dybczak 2019), mindez önmagában nem magyarázza a környező országokhoz képesti eltéréseket, hiszen ez a jelenség Európa szinte valamennyi államában megfigyelhető.

Hazánk esetében további érdekes következtetések vonhatók le a forgalomban lévő készpénzállomány, a jegybanki alapkamat és az euroárfolyam együttes vizsgálatából (7. ábra). Megfigyelhető, hogy 2008 és 2012 között az EUR/HUF árfolyam és a készpénzmennyiség megváltozásai jellemzően azonos irányba mutatnak, azaz a forint euróhoz képest történő gyengülése a készpénzkereslet növekedésével járt együtt. A fontosabb nemzetközi valutákat tekintve hasonló jelenségek tapasztalhatók (lásd például Miller 2017), ezek hátterében azonban elsősorban a külföldről érkező kereslet áll, ami a forint esetében vélhetően elhanyagolható mértékű. Magyarországon a vizsgált időszakban dominánsabb lehet az árfolyam, mint a pénzügyi-gazdasági rendszer stabilitását és teljesítményét jelző indikátor szerepe, mivel a forint hirtelen gyengülései jellemzően válsághelyzetekhez kapcsolódtak, amelyek együtt járhattak a lakosság bankrendszerbe vetett bizalmának csökkenésével is.

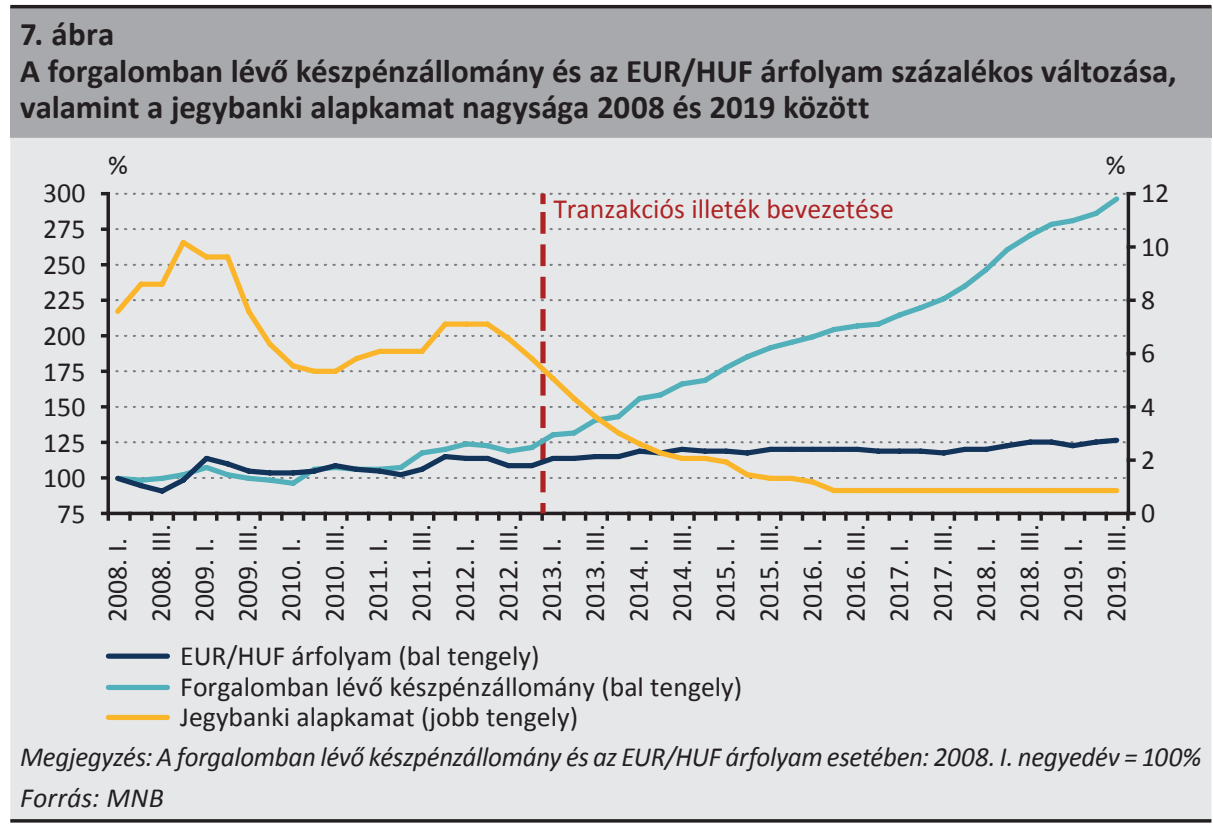


A 7. ábrán jól megfigyelhető az adatsorokban 2012-2013-ban jelentkező töréspont, azaz a készpénzállomány növekedésének gyorsulása, ami hozzávetőlegesen egybeesik a kamatcsökkentési időszak kezdetével is. Az alacsonyabb kamatkörnyezetben a készpénz már nem csupán „menekülőútként” szolgálhat, hanem hosszabb távon is reális megtakarítási formaként. Ugyanekkor került sor a tranzakciós illeték bevezetésére is, ami szintén szignifikáns hatással lehetett a készpénz iránti keresletre, elsősorban a nagy címletek tranzakciós használatán keresztül (részletesebben lásd jelen alfejezet végén).

A lakossági megtakarítási szokásokról, illetve az azokat befolyásoló tényezőkről az elmúlt években az Európai Központi Bank koordinálásával két hullámban zajlott felméréssorozat, amelyben mind az MNB (MNB 2017 és MNB 2019b), mind pedig a lengyel jegybank (NBP 2015 és NBP 2017) részt vett. A felmérések közös tanulsága, hogy a vizsgált években a jövedelmek emelkedésével összhangban mindkét országban számottevően nőtt a háztartások pénzügyi eszközeinek értéke, a készpénztartásra vonatkozó kérdések esetén azonban igen alacsony volt a válaszadási hajlandóság, így ezek esetében célszerű a nemzeti számlák adataira támaszkodni.

A 2008 és 2018 közötti KSH-adatokat megvizsgálva jól látható, hogy 2012-től kezdve a készpénzes megtakarítások értéke folyamatos, erős ütemű növekedést mutat, míg a betétállományok bővülése jóval visszafogottabb (8. ábra). Figyelemre méltó, hogy 2012 és 2018 között a készpénz aránya a háztartások pénzeszközein belül 21-ről 33 százalékra nőtt. Jobst - Stix (2017) alapján ennek lehetséges okai között szerepelhet a 2007-2009-es gazdasági válság, illetve az eurozóna 2010-2013 közötti válsága által keltett pénzügyi és társadalmi bizonytalanság, ami a lakosságot a megbízhatóbbnak ítélt készpénz tartása felé terelhette. Hazánkban ezt a hatást, illetve az ennek kö-

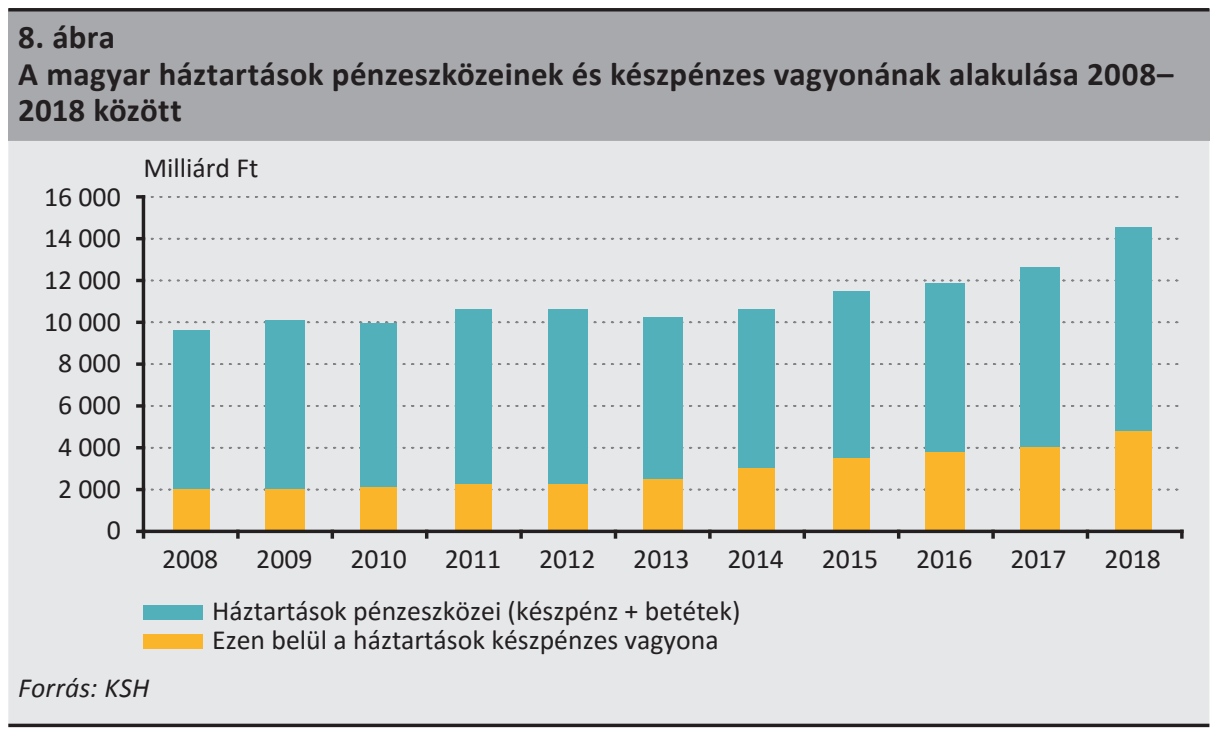


vetkezményeként a bankok iránt fellépő bizalmatlanságot tovább erősíthette, hogy 2014-ben és 2015-ben több brókercég és hitelintézet is végelszámolás alá került.

A 2019 júniusától kezdve kibocsátott, mérsékelt kockázat mellett a piacon elérhetőnél magasabb hozamokat nyújtó Magyar Állampapír Plusz konstrukció céljai között szerepelt a háztartások készpénzes megtakarításainak becsatornázása is, ez azonban az MNB adatai szerint az első hónapokban nem valósult meg. A forgalomban lévő készpénzállomány 2019 júniusa és szeptembere között az előző év azonos időszakához viszonyítva ugyan - lassuló ütemben - nőtt (135, illetve 278 milliárd forintos növekedés), ez azonban alapvetően megfelel a 2019 első 5 hónapjában megfigyelhető, szintén lassulást mutató trendeknek (62, illetve 350 milliárd forintos növekedés).

A háztartások készpénzben tartott pénzeszközei arányának növekedése a környező országokkal, valamint az eurozónával összehasonlítva is kiugrónak mondható, bár 2012-től kezdve Románia, valamint Lengyelország esetén is megfigyelhető kisebb mértékú eltolódás a készpénztartás irányába (9. ábra). A bankszektor válságainak, valamint az ebből eredő gazdasági bizonytalanságnak a készpénzállományra gyakorolt hatását specifikusan Magyarországot tekintve Lybek - Dybczak (2019) 2000 és 2018 közötti adatok felhasználásával, regresszióelemzéssel vizsgálta, szignifikáns korrelációt azonban a szerzőknek nem sikerült kimutatniuk. Bár az említett jelenségek hatása a lakosság gondolkodására nehezen számszerüsíthető, ami csökkentheti az eredmények megbízhatóságát, mindez mégis arra enged következtetni, hogy önmagukban az elmúlt évtized válságai nem adnak megfelelő magyarázatot a hazai készpénzigény erős növekedésére.

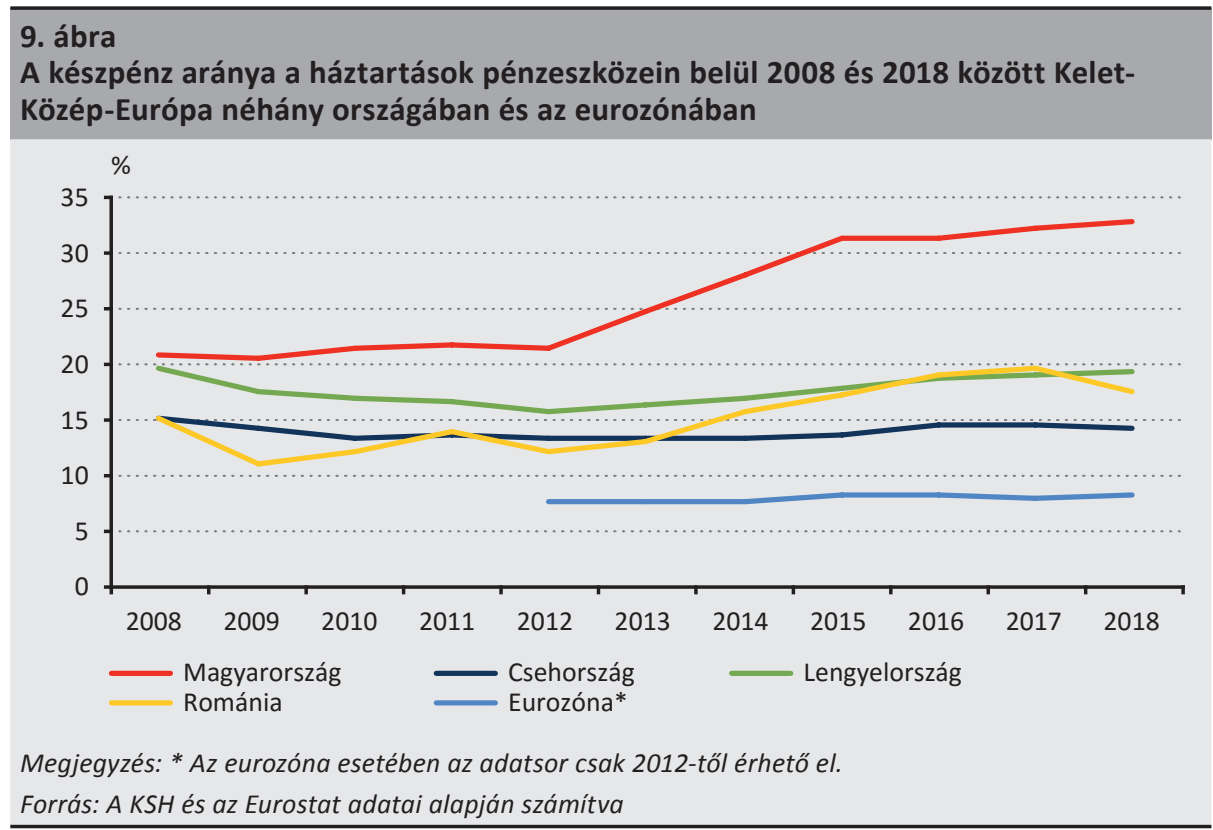


Érdemes annak lehetőségét sem figyelmen kívül hagyni, hogy a nagy címletek bizonyos esetekben tranzakciós célokat is szolgálhatnak, így a készpénztartás a hoszszú távú megtakarítás mellett irányulhat jövőbeli tranzakciók kiegyenlítésére is. Flannigan - Parsons (2018) korábban említett eredményei szerint ilyen tranzakciók lehetnek a lakásvásárláshoz és -felújításhoz kapcsolódó kifizetések, a hazai és a környező országok ingatlanárindexei (az MNB és az Eurostat adatait felhasználva) azonban nem mutatnak szignifikáns korrelációt a készpénz iránti kereslettel, amit jól illusztrál, hogy Romániában 2008 és 2018 között az árindex csökkenése mellett valósult meg a készpénzállomány erős növekedése.

A nagy címletek tranzakciós használatának irányába hathat azonban az ebben a formában csak hazánkra jellemző tranzakciós illeték, amely a lakossági és vállalati banki tranzakciókra (elóbbi esetén csak 20000 forint felett), valamint a készpénzfelvételekre is vonatkozik (a törvény által elöírt havi kétszeri, legfeljebb 150000 forint értékú ingyenes felvételt leszámítva). Belházyné et al. (2018) felmérésen alapuló eredményei alapján a hazai KKV-szektorban 2013 és 2017 között megfigyelhető volt a nagyobb összegú készpénzes tranzakciók gyakoribbá válása, Végső et al. (2018) szerint pedig a magyar háztartások európai összehasonlításban alkalmanként jelentősen nagyobb összegű készpénzt vesznek fel banki költségeik optimalizálása érdekében, ami szükségszerúen együtt jár azzal is, hogy a felvett készpénz több nagy címletű bankjegyet is tartalmaz. A tranzakciós illeték bevezetése Lybek - Dybczak (2019) regresszióelemzése szerint is jól magyarázza a készpénzigény 2013 után megfigyelhető, a korábbinál is erősebb növekedését (7. ábra). A szerzők szerint azonban a 2020 márciusában induló, valamennyi bankot érintő azonnali fizetési rendszer - a megfelelő árazás mellett - fontos szerepet játszhat a készpénzes tranzakciók mértékének visszaszorításában.

\subsection{A nemzetközi példák tanulságai}

A továbbiakban részletesebben ismertetjük néhány, az előző alfejezetben nem tárgyalt, de a 6. ábrán szereplő ország készpénzforgalmi jellemzőit, elsősorban azokra az államokra koncentrálva, amelyek egyedi, jól körülhatárolható jellegzetességekkel rendelkeznek.

\subsubsection{Svédország}

A vizsgált országok közül a legkülönlegesebbnek Svédország helyzete tekinthető, hiszen az elmúlt évtizedben - Norvégiát leszámítva, ahol ez a trend csak 2015 óta figyelhető meg - egyedül itt valósult meg a nominális készpénzállomány tartós és folyamatos csökkenése, emellett pedig 2012 és 2018 között a GDP-arányos készpénzállomány is a felére esett vissza. Arvidsson (2019) szerint a jelenségben kiemelt szerepe volt a svéd jegybank azon döntésének, mely szerint a 2010-es években az új bankjegysorozat kibocsátásakor a régi, forgalomból bevont nagy értékű papírpénzek beváltására igen rövid, mindössze néhány hónapos határidőt biztosított. 
Ez - együttesen az országban ezt megelőzően lezajlott, komoly publicitást kapott bankrablássorozattal - nagymértékben aláásta a készpénzbe mint egyszerű és biztonságos megtakarítási eszközbe vetett hitet. Ezzel egyidőben a svéd kormány gazdaságfehérítő és adóelkerülést csökkentő intézkedéseket hajtott végre, melyek kiemelten célozták az építőipart és a különféle háztartási szolgáltatásokat (pl. kertészkedés, gyerekvigyázás), ezáltal csökkentve elsősorban a tranzakciós, de kisebb mértékben a megtakarítási célú készpénzkeresletet is. Ezenfelül mind Arvidsson (2019), mind pedig Engert et al. (2019) kiemeli a készpénzmentes bankfiókok terjedésének szerepét, mely egyrészt a kiskereskedőket is az elektronikus fizetések előnyben részesítésére ösztönözte mind vevői, mind pedig beszállítói kapcsolataikban, másrészt a készpénz felhasználhatóságának korlátozásával feltételezhetően tovább csökkentette a készpénzben történő megtakarítás népszerüségét.

Összességében megállapítható, hogy Svédországban elsősorban a megtakarítási célú készpénzkereslet mérséklésével sikerült elérni a készpénzállomány tartós és jelentős csökkenését. A tranzakciós készpénzhasználat visszaszorulása hasonló mértékű volt számos más, fejlett országban, többek között Norvégiában, Dániában (Smestad 2017), Kanadában (Engert et al. 2019), Hollandiában (Jonker et al. 2018) vagy az Egyesült Királyságban is (Greenham - Travers-Smith 2019), ez azonban önmagában nem volt elegendő a nominális állomány csökkentéséhez.

Mindezek mellett azonban érdemes megemlíteni, hogy az euro bankjegyek 2002-es kibocsátása után a Svédországgal szomszédos Finnországban a vártnál sokkal erősebb növekedés volt tapasztalható a készpénzkeresletben, melyet a helyi lakossági tranzakciók adatai nem támasztottak alá (Kangas 2019). Mivel ez az időszak nagyjából egybeesik a Svédországban megfigyelt csökkenés 2006-2007-es kezdetével, akár az is elképzelhető, hogy a svéd lakosság készpénzes megtakarításai egy részét svéd korona helyett Finnországból származó euro bankjegyek formájában tartja.

\subsubsection{Izrael}

Izrael példája magyar szempontból kiemelten relevánsnak tekinthető, mivel azon kevés ország egyikéről van szó, ahol hazánkhoz hasonlóan a két legnagyobb címletű bankjegy teszi ki a forgalomban lévő készpénzállomány túlnyomó részét (a jegybank 2018. végi adatai szerint 54, illetve 27 százalékát). Az izraeli kormány feltételezései szerint a nagy címletű bankjegyek segítik az adóelkerülést, valamint a rejtett gazdaság múködését, ezért 2015-ben törvényjavaslat született a nagy összegű készpénzes tranzakciók betiltása, valamint a főként kulturális okokból eredő túlzott készpénztartás visszaszorítása érdekében, amely mind az üzleti, mind a magánszemélyek közötti fizetésekre vonatkozott (Fein 2018). A javaslatot az izraeli parlament több módosítást és hosszas társadalmi vitákat követően 2018 februárjában fogadta el, a törvény pedig 2019. január 1-jén lépett életbe (Fein 2019).

\footnotetext{
${ }^{6} \mathrm{~A} 200$ sékeles bankjegy értéke 2019. decemberi árfolyamon körülbelül 17000 forint.
} 
A törvény a készpénzes tranzakciókat az üzleti életben 11000 sékelben (vásárlóerőparitással korrigálva kb. 380000 forint), magánszemélyek között 50000 sékelben (vásárlóerőparitással korrigálva kb. 1,74 millió forint) maximalizálta. Az izraeli jegybank adatai szerint a bevezetés után, 2019 folyamán az országban forgalomban lévő készpénzállomány értéke stagnált, ez azonban nem tér el számottevően a korábbi évek lassuló ütemű növekedést mutató trendjétől. A jövőben ezért tanulságos lehet annak vizsgálata, hogy a törvény hatására hosszabb távon megváltozik-e az izraeli készpénzállomány összetétele, megvalósul-e az adóbevételek várt növekedése és a rejtett gazdaság visszaszorulása, valamint okoz-e az intézkedés számottevő problémákat a lakosság azon részének, amely nem rendelkezik bankszámlához való hozzáféréssel.

\subsubsection{India}

India kormánya 2016-ban még drasztikusabb módszerrel, az úgynevezett „demonetizációval” próbálta visszaszorítani a rejtett gazdasághoz köthető, nagy összegű készpénzes tranzakciókat és megtakarításokat. Narendra Modi miniszterelnök november 8-i, váratlan bejelentésekor a legnagyobb címletű, 500 és 1000 rúpiás bankjegyek aznap éjféli hatállyal bevonásra kerültek, átváltásukra pedig csupán az év végéig adtak lehetőséget a lakosságnak. Az indiai jegybank jelentése szerint (Reserve Bank of India 2017) a kijelölt határidőig a bevont bankjegyek több mint 99 százaléka átváltásra került, a GDP-arányos készpénzállomány pedig csak ideiglenesen csökkent.

Ebből adódóan a lépés eredeti célját csak korlátozottan érte el, viszont országszerte komoly válsághelyzetet okozott, ami hatással volt a mezőgazdasági termelésre és a foglalkoztatásra is. A demonetizáció során átmenetileg fellépő készpénzhiány a kormány szándékaival ellentétben erősítette az informális gazdaság szerepét, öszszességében pedig elsősorban a vidéken élő, szegényebb, nagy összegű megtakarításokkal és bankszámlához való hozzáféréssel nem rendelkező rétegeket sújtotta (Guérin et al. 2017). Emellett Chodorow-Reich et al. (2018) matematikai modellek segítségével megerősítették, hogy azokban a régiókban, ahol a demonetizáció nyomán fellépő készpénzhiány nagyobb mértékű volt, erősebb visszaesés következett be a gazdaság teljesítményében és a hitelezésben is.

\subsubsection{Kína}

A kínai háztartások tradicionálisan magas - bár az elmúlt években némileg csökkenő - megtakarítási rátával rendelkeznek, ezen belül pedig jelentős a készpénzes megtakarítások részesedése is (Zhang et al. 2018). A 2010-es években lezajlott pénzügyi liberalizáció, valamint az egyre jelentősebbé váló árnyékbankrendszer (Elliott et al. 2015) által nyújtott magasabb hozamok eredményeként azonban a készpénztartás népszerűsége napjainkra visszaszorulni látszik, ennek következménye a GDP-arányos készpénzállomány csökkenése is. Mindezt az is elősegítheti, hogy a kínai jüan legnagyobb címletű bankjegyének értéke az 5000 forintot sem éri 
el7 . Érdemes megemlíteni, hogy a kínai fizetési forgalomra kimagasló mértékben jellemző az innovatív, készpénzmentes megoldások gyors elterjedése. Ezalatt elsősorban a mobiltelefonos fizetést érthetjük (G4S 2018), de itt jelentek meg először nagyobb számban az arcfelismerésen alapuló, tehát a tranzakcióhoz semmilyen egyéb eszköz használatát nem igénylő fizetési módok is.

\subsubsection{Dél-Korea és Japán}

Ezen két ország elsősorban azért érdemel említést, mert a kelet-ázsiai régióban az elmúlt évek során kizárólag esetükben volt megfigyelhető a GDP-arányos készpénzállomány erős ütemú növekedése. Japánban a növekedés eleve igen magas bázisról történt, melynek fő oka Fujiki - Nakashima (2019) szerint a megtakarítási célú készpénzkereslet, mely a teljes állomány 40-45 százalékáért felel. A szerzők szerint a készpénzes megtakarítások bővülése az elmúlt években és napjainkban is meghaladja az elektronikus fizetési megoldások terjedéséből eredő csökkenést. A nagymértékú készpénztartás okai között szerepelhet az 1990-es évek közepe óta nulla közeli alapkamatszint, a társadalom elöregedése, valamint akár ezzel összefüggésben a kiugró mértékű örökösödési adó elkerülése is (Shirai - Sugandi 2019).

Dél-Korea esetében a GDP-arányos készpénzállomány a 2010-es évek elején még alacsonynak volt mondható, az elmúlt évtizedben azonban a forgalomban lévő készpénzállomány mennyisége olyan dinamikusan emelkedett, hogy annak GDP-növekedéshez viszonyított üteme a hazánkra jellemző értékeket is szignifikánsan meghaladta (6. ábra). Ebben vélhetően fontos szerepet játszanak a készpénzben tartott megtakarítások, amit az is alátámaszt, hogy a koreai jegybank a növekedést megelőzően, 2009-ben új, az addig forgalomban lévő címleteknél nagyobb értékű bankjegyet bocsátott $\mathrm{ki}^{8}$

Érdemes megemlíteni, hogy mindezzel egyidőben a koreai jegybank adatai szerint a tranzakciós célú készpénzhasználat folyamatos és gyors ütemú csökkenést mutat, napjainkban a fizetések több mint 80 százaléka elektronikus úton történik, 2017ben pedig kísérletképpen elindításra került az érmementességet célzó program is, melynek lényege, hogy a vásárlók a kis összegú visszajárót igény szerint közvetlenül bankszámlájukra, vagy megadott helyeken felhasználható feltöltőkártyára kapják9.

\footnotetext{
${ }^{7}$ A 100 jüanos bankjegy értéke 2019. decemberi árfolyamon körülbelül 4200 forint.

${ }^{8} \mathrm{Az} 50000$ wonos bankjegy értéke 2019. decemberi árfolyamon körülbelül 12600 forint.

${ }^{9}$ Currency News (2017): South Korea Plans to go 'Coinless'. Currency News, 2017, 15 January, p. 3.
} 


\section{Mit hozhat a jövő?}

Mivel mind a teljes világgazdaság, mind pedig az egyes nemzetek készpénzigénye rendkívül összetett folyamatok eredőjeként alakul ki, az erre vonatkozó hosszabb távú prognózisok gyakran igen pontatlannak bizonyulnak. Ezen fejezet röviden ismerteti az előrejelzések lehetséges módszertanát és annak korlátait, majd egy lehetséges jövőképként bemutatja a készpénzmentes társadalom lehetőségét és társadalmi kockázatait, érintve a jegybankok által kibocsátott digitális pénz kérdését is.

\subsection{A készpénzkereslet előrejelzésének lehetőségei}

A készpénzforgalom és a készpénz iránti kereslet az elmúlt évtizedben számos strukturális változáson ment keresztül, ami az előrejelzések készítését is megnehezíti, hiszen ennek következtében a múltbeli adatok csak igen kis magyarázó erővel bírnak a jövőre nézve. A jegybankok munkatársai és az elemzők a fejlett világban a készpénzhasználat további csökkenését vetítik előre (például Lalouette - Esselink 2018 az eurozónára, vagy Perkins 2019 az USA-ra vonatkozóan), napjainkra azonban már nyilvánvalóvá vált, hogy ez a jelenség nem feltétlenül vonja maga után a forgalomban lévő készpénzállományok csökkenését.

Miller (2017) az angol jegybank által használt módszertani keretrendszer ismertetésén keresztül bemutatja a készpénz iránti kereslet összetevőkre bontásának szerepét ${ }^{10}$, valamint azt, hogy a kellő robusztussághoz az ökonometriai modellezés mellett - amely figyelembe veszi például a lakossági fogyasztást, a kamatkörnyezetet vagy az árfolyamokat - célszerű kvalitatív jelleggel figyelembe venni a szabályozási környezet lehetséges megváltozásait vagy a technológiai fejlődés különböző irányait is. Kiemeli emellett annak fontosságát is, hogy az előrejelzések elsődleges célja a készpénz esetében nem a jövőben megvalósuló pontos értékek megállapítása, hanem a lehetséges kimenetelek tartományának meghatározása, az azokat kísérő valószínűségekkel együtt.

\subsection{A készpénzmentes társadalom víziója és kockázatai}

Bár a hazai, vagy akár az európai uniós összesített adatokat vizsgálva igen távolinak érződhet a készpénz teljes eltűnése, a svéd jegybank vezetői már a készpénzmentes társadalom lehetőségére igyekeznek felkészíteni országuk lakosságát (Skingsley 2018). A készpénzmentesség azonban nem mindenki számára jelent pozitív változásokat. Egy - a tranzakciós készpénzhasználat visszaszorításában szintén élen járó Nagy-Britannia számára ajánlásokat megfogalmazó - elemzés szerint (Greenham - Travers-Smith 2019) a brit lakosság 12 százaléka saját bevallása szerint készpénz nélkül képtelen lenni elintézni mindennapi tranzakcióit. Ebbe a csoportba főként idősek és alacsony jövedelműek tartoznak, vagyis a készpénz eltűnése a társadalom

${ }^{10}$ Tranzakciós célú készpénz, megtakarítási célú készpénz, külföldi kereslet, valamint a rejtett gazdaság által használt készpénz, részletesebben lásd 4. fejezet. 
egyébként is sérülékeny rétegeit érintené a legérzékenyebben. Sokakat érinthet negativan továbbá az anonimitás lehetőségének megszűnése, valamint az érintett országokban elvégzett lakossági felmérésekből is kitűnik (Dánia esetén lásd például Smestad 2017) hogy az emberek nem elhanyagolható része pusztán szubjektív okok miatt is szeretné, ha a készpénz továbbra is elérhető maradna.

A társadalmi kockázatokon felül a fizetések teljes mértékben elektronikus útra történő terelése egyéb, főként technológiai jellegű rizikókat is hordoz magában. Almedia et al. (2018) szerint egy készpénzmentes társadalomban a kommunikációs és az elektromos hálózatok, valamint a fizetési rendszereket müködtető szerverek esetleges hibái - melyeket okozhat természeti katasztrófa, de akár külső támadás is - a jelenleginél sokkal nagyobb kockázatot képviselnének. A Fed adatai alapján (Bau - O’Brien 2019) az Egyesült Államokban a közelmúlt természeti csapásai (például a 2017-ben Texas és Louisiana államokat sújtó Harvey hurrikán) lokálisan rendkívül nagy készpénzkeresletet generáltak az érintett területeken, akár már a katasztrófa tényleges bekövetkeztét megelőző hetekben is. A jelenség megerősíti, hogy a lakosság számára igen fontos a készpénz mint biztonsági tartalék szerepe.

Mindezek eredményeként jelenleg a közbeszédben és a jegybankok kommunikációjában a készpénzmentesség („cashless”) fogalma helyett sokkal gyakoribb a kevesebb készpénz („less-cash”) felé való törekvés kihangsúlyozása (John 2019). A tranzakciós készpénzhasználat folyamatos csökkenése hosszú távon ugyan a készpénz mint fizetési eszköz teljes eltűnése felé mutat, azonban egyrészt jelenlegi tapasztalataink szerint ez nem feltétlenül jár együtt a készpénz mint megtakarítási forma iránti igényének megszűnésével, másrészt a készpénzmentességet kísérő társadalmi aggályok is indokolttá tehetik a készpénzes infrastruktúra további évtizedekig történő fenntartását.

A bankjegyek és érmék teljes eltüntetésére irányuló víziók fontos eleme a jegybankok által kibocsátott digitális pénzek lehetősége. Egy ilyen megoldás ideális esetben úgy biztosít lehetőséget a készpénzhez kapcsolódó gyártási és disztribúciós költségek megszüntetésére, hogy - megfelelő állami és jegybanki felügyelet mellett - a lakosság semmilyen részét nem fenyegeti a pénzügyi rendszeren kívül rekedés lehetősége, hiszen megszüntethető a kereskedelmi bankok és kártyatársaságok monopóliuma az elektronikus fizetések terén. Bár pilot projektekkel, valamint a megvalósítás lehetőségeit vizsgáló kutatásokkal számos ország esetén találkozhatunk (Mancini-Griffoli et al. 2018 alapján pl. Kanada, Kína, Norvégia, Uruguay), a gyakorlatban megvalósult digitális jegybankpénzre jelenleg még nem létezik példa, a legelőrehaladottabb állapotban azonban feltehetően a svéd központi bank tervei állnak (Söderberg 2018). A témáról a közelmúltban a BIS (Barontini - Holden 2019) nemzetközi felmérést, az IMF (Khiaonarong - Humphrey 2019) pedig átfogó tanulmányt közölt. 


\section{6. Összefoglalás}

Ha tehát feltesszük a kérdést, hogy túl sok készpénzt használunk-e, leginkább úgy válaszolható meg: bár a fizetések lebonyolításához nem használunk túl sokat belőle, mégis kijelenthető, hogy napjainkban a környező országok példájához képest hazánkban túl nagy a forgalomban lévő készpénz mennyisége, amely azonban elsősorban megtakarítási célokat szolgál. Magyarországon továbbra is van tér az elektronikus fizetési megoldások részesedésének növelésére, de elmondható, hogy a nemzetközi trendeknek megfelelően egyre kevesebben és kevesebbet fizetünk készpénzzel. A forgalomban lévő készpénzállomány ezzel szemben mind hazánkban, mind a fejlett államok nagy részében tartósan emelkedik, jellemzően a GDP-növekedés üteménél is gyorsabban. A változás fő mozgatórugói Magyarország esetében nem példa nélküli módon - a nagyobb címletű bankjegyek, melyeket a lakosság nem csupán fizetési, hanem megtakarítási eszközként is használ. Ennek oka lehet többek között a tartósan alacsony kamatkörnyezet és az elmúlt évtized gazdasági válságai által keltett bizonytalanság, illetve ennek következményeként a bankrendszerrel szemben tapasztalható bizalmatlanság is. Nem elhanyagolható továbbá a tranzakciós illeték szerepe sem, mely feltehetően hatással van a nagyobb összegú készpénzes tranzakciók mértékére is.

A hazai növekvő készpénzigény első ránézésre kirívónak tűnhet, a forgalomban lévő készpénzállomány tartós csökkenésére azonban nemzetközi szinten is csak igen kevés példa létezik, ennek eléréséhez pedig valamennyi esetben több, a készpénz használata és tartása ellen irányuló tényező együttes fennállása volt szükséges. Magyarország esetében is elképzelhető viszont, hogy a készpénzállomány átlagos bővülési üteme akár rövid távon is az eurozónára vagy Csehországra jellemző értékek közelébe csökkenjen. Ennek eléréséhez a jövőben különösen nagy előrelépést jelenthet az azonnali fizetési rendszer 2020-ban történő elindulása, de ugyanígy kedvező változásokat indukálhat a banki szolgáltatások díjainak mérséklése vagy a lakosság számára elérhető, vonzó hozamot kínáló, mégis mérsékelt kockázattal bíró megtakarítási formák további népszerűsége is (például a 2019-ben kibocsátott Magyar Állampapír Plusz). A közelmúlt nemzetközi trendjeinek, valamint az ezeken alapuló kutatásoknak azonban fontos tanulsága - mely a jövőben a hazai készpénzkeresletet is befolyásolhatja - hogy globális gazdasági recessziót vagy válsághelyzetet követően a lakosság készpénzigénye akár hosszabb időtávon is szignifikánsan növekedhet. 


\section{Felhasznált irodalom}

Almedia, P. - Fazendeiro, P. - Inácio, P.R.M. (2018): Societal risks of the end of physical cash. Futures, 104(December): 47-60. https://doi.org/10.1016/j.futures.2018.07.004

Anderson, P S. (1977): Currency in use and in hoards. New England Economic Review, March/ April, pp. 21-30.

Arango, C.A. - Huyhn, K.P. - Sabetti, L. (2015): Consumer payment choice: Merchant card acceptance versus pricing incentives. Journal of Banking \& Finance, 55(June): 130-141. https://doi.org/10.1016/j.jbankfin.2015.02.005

Arango-Arango, C.A. - Suárez-Ariza, N.F. (2019): Digital Payments Adoption and the Demand for Cash: New International Evidence. Borradores de Economía, No. 1074. https://doi. org/10.32468/be.1074

Arvidsson, N. (2019): The Story of Cash and the Route Toward a Cashless Society: The Case of Sweden. In: Arvidsson, N. (ed.): Building a Cashless Society, Springer, Cham, pp. 27-40. https://doi.org/10.1007/978-3-030-10689-8_4

Assenmacher, K. - Seitz, F. - Tenhofer, J. (2019): The demand for Swiss banknotes: some new evidence. SNB Working Papers 2/2019, February. https://doi.org/10.1186/s41937019-0041-7

Barontini, C. - Holden, H. (2019): Proceeding with caution - a survey on central bank digital currency. BIS Papers No 101, January.

Bartzsch, N. - Rösl, G. - Seitz, F. (2011a): Foreign demand for euro banknotes issued in Germany: estimation using direct approaches. Deutsche Bundesbank Discussion Paper Series 1: Economic Studies No. 20.

Bartzsch, N. - Rösl, G. - Seitz, F. (2011b): Foreign demand for euro banknotes issued in Germany: estimation using indirect approaches. Deutsche Bundesbank Discussion Paper Series 1: Economic Studies No. 21.

Bau, A. - O'Brien, S. (2019): Rethinking Volume Forecasting: Observing cash's evolution in the economy, and the subsequent impact on the cash handling industry. Elöadás: Future of Cash Conference, Athén, Február 19-21.

Bech, M. - Shimizu, Y. - Wong, P. (2017): The quest for speed in payments. BIS Quarterly Review, March, pp. 57-68.

Bech, M. - Faruqui, U. - Ougaard, F. - Picillo, C. (2018): Payments are a-changin' but cash still rules. BIS Quarterly Review, March, pp. 67-80. 
Belházyné Illés Ágnes - Bódi-Schubert Anikó - Végső Tamás (2018): A magyarországi mikro-, kis- és középvállalkozások fizetési szokásainak elemzése - fókuszban a készpénzhasználat. Hitelintézeti Szemle, 17(4): 53-94. http://doi.org/10.25201/HSZ.17.4.5394

Chodorow-Reich, G. - Gopinath, G. - Mishra, P. - Narayanan, A. (2018): Cash and the Economy: Evidence from India's Demonetization. NBER Working Paper No. 25370, December. https://doi.org/10.3386/w25370

Doyle, M.-A. - Fisher, C. - Tellez, E. - Yadav, A. (2017): How Australians Pay: Evidence from the 2016 Consumer Payments Survey. RBA Research Discussion Papers, April. https://www.rba. gov.au/publications/rdp/2017/pdf/rdp2017-04.pdf. Letöltés ideje: 2019. szeptember 13.

Deutsche Bundesbank (2018): Payment behaviour in Germany in 2017. https://www.bundesbank.de/resource/blob/737278/\%20458ccd8a8367fe8b36bbfb501b5404c9/mL/paymentbehaviour-in-germany-in-2017-data.pdf. Letöltés ideje: 2019. szeptember 13.

Deutsche Bundesbank (2019): Cash demand in the shadow economy. Monthly Report March 2019, pp. 43-58. https://www.bundesbank.de/resource/blob/793190/466691bce4f27f76407b35f8429441ae/mL/2019-03-bargeld-data.pdf. Letöltés ideje: 2019. szeptember 13.

Elliott, D. - Kroeber, A. - Qiao, Y. (2015): Shadow banking in China: A primer. Brookings Economic Studies, March.

Engert, W. - Fung, B.S.C. - Segendorf, B. (2019): A Tale of Two Countries: Cash Demand in Canada and Sweden. Bank of Canada Staff Discussion Paper 2019-7. https://www. bankofcanada.ca/wp-content/uploads/2019/08/sdp2019-7.pdf. Letöltés ideje: 2019. szeptember 13.

Esselink, H. - Hernández, L. (2017): The use of cash by households in the euro area. ECB Occasional Paper Series No. 201, November.

Fein, M. (2018): Limitations on the Use of Cash in Israel: A New Law. CashEssentials. https:// cashessentials.org/app/uploads/2018/07/cashlimitationsinisrael_may2018_update_mordechai_fein.pdf. Letöltés ideje: 2019. szeptember 13.

Fein, M. (2019): New Cash Law sparks panic in Israel. CashEssentials. https://cashessentials. org/new-cash-law-sparks-panic-in-israel/. Letöltés ideje: 2019. szeptember 13.

FIS (2018): Flavors of Fast report. http://empower1.fisglobal.com/rs/650-KGE-239/images/ FLAVOR-OF-FAST-Report-2018.pdf. Letöltés ideje: 2019. szeptember 13.

Flannigan, G. - Parsons, S. (2018): High denomination banknotes in circulation: A cross-country analysis. RBA Bulletin, March, pp. 1-19. 
Fujiki, H. - Nakashima, K. (2019): Cash Usage Trends in Japan: Evidence Using Aggregate and Household Survey Data. TCER Working Paper E-131, March. https://doi.org/10.2139/ ssrn.3351429

Fujiki, H. - Tanaka, M. (2018): How do we choose to pay using evolving retail payment technologies? Evidence from Japan. Journal of the Japanese and International Economics, 49(May): 85-99. https://doi.org/10.1016/j.jjie.2018.05.001

Fung, B. - Huynh, K.P. - Stuber, G. (2015): The Use of Cash in Canada. Bank of Canada Review, Spring, pp. 45-56.

G4S (2018): World Cash Report. https://www.g4scashreport.com/. Letöltés ideje: 2019. szeptember 13.

Greene, C. - Stavins, J. (2018): The 2016 and 2017 Surveys of Consumer Payment Choice: Summary Results. Fed Boston Research Data Reports, No. 18-3, May.

Greenham, T. - Travers-Smith, F. (2019): Cashing Out: the hidden costs and consequences of moving to a cashless society. RSA Report, January. https://www.thersa.org/globalassets/ pdfs/reports/rsa-cashing-out.pdf. Letöltés ideje: 2019. szeptember 13.

Guérin, I. - Lanos, Y. - Michiels, S. - Nordman, C.J. - Venkatasubramanian, G. (2017): Demonetisation, Social Networks and Social Protection: Insights from Rural Tamil Nadu. IRD Working Papers 2017/10, October.

Ilyés Tamás - Varga Lóránt (2015): Mutasd, mivel fizetsz, megmondom, ki vagy - A pénzforgalmi szokásokat befolyásoló szociodemográfiai tényezők. Hitelintézeti Szemle, 14(2): 26-61. https://hitelintezetiszemle.mnb.hu/letoltes/2-ilyes-varga.pdf

Immordino, G. - Russo, F.F. (2018): Cashless payments and tax evasion. European Journal of Political Economy, 55(November): 36-43. https://doi.org/10.1016/j.ejpoleco.2017.11.001

Jobst, C. - Stix, H. (2017): Is cash back? Assessing the recent increase in cash demand. SUERF Policy Note, Issue No. 19, October.

John, S. (2019): Less-cash, but not cashless. Előadás: Currency Conference, Dubai, April 7-11. https://www.bankofengland.co.uk/-/media/boe/files/speech/2019/less-cash-butnot-cashless-speech-by-sarah-john. Letöltés ideje: 2019. szeptember 13.

Jonker, N. - Hernandez, L. - de Vree, R. - Zwaan, P. (2018): From cash to cards: how debit card payments overtook cash in the Netherlands. DNB Occasional Studies, Volume 16-1, January.

Judson, R. (2017): The Death of Cash? Not So Fast: Demand for U.S. Currency at Home and Abroad, 1990-2016. Előadás: International Cash Conference 2017, Mainau, April 25-27. 
Kangas, J. (2019): How can we (not) estimate the cash usage in Finland? Előadás: Future of Cash Conference, Athén, Február 19-21.

Khan, J. - Belk, R.W. - Craig-Lees, M. (2015): Measuring consumer perceptions of payment mode. Journal of Economic Psychology, 47(January): 37-49. https://doi.org/10.1016/j. joep.2015.01.006

Khiaonarong, T. - Humphrey, D. (2019): Cash Use Across Countries and the Demand for Central Bank Digital Currency. IMF Working Paper 19/46, March. https://doi. org/10.5089/9781484399606.001

Lalouette, L. - Esselink, H. (2018): Trends and developments in the use of euro cash over the past ten years. ECB Economic Bulletin, Issue 6, pp. 87-109.

Lybek, T. - Dybczak, K. (2019): Hungary Selected Issues. IMF Country Report No. 19/358, December. https://doi.org/10.5089/9781513521435.002

Mancini-Griffoli, T. - Peria, M.S.M. - Agur, I. - Ari, A. - Kiff, J. - Popescu, A. - Rochon, C. (2018): Casting Light on Central Bank Digital Currency. IMF Staff Discussion Note 18/08, November. https://doi.org/10.5089/9781484384572.006

Miller, C. (2017): Addressing the limitations of forecasting banknote demand. Előadás: International Cash Conference 2017, Mainau, április 25-27. https://www.bankofengland. co.uk/-/media/boe/files/paper/2017/addressing-the-limitations-of-forecasting-banknote-demand. Letöltés ideje: 2020. január 10.

MNB (2017): A háztartási szektor pénzügyi megtakarításai mikro- és makrostatisztikai adatok alapján. 2017. https://www.mnb.hu/letoltes/haztartasok-hun-0531.pdf. Letöltés ideje: 2019. december 13.

MNB (2019a): Fizetési rendszer jelentés. 2019, július. https://www.mnb.hu/letoltes/fizetesi-rendszer-jelentes-2019-hun-vegleges.pdf. Letöltés ideje: 2019. szeptember 13.

MNB (2019b): Miból élünk? A 2017-es háztartási vagyonfelmérés első eredményeinek bemutatása. 2019. https://www.mnb.hu/letoltes/vagyonfelmeres-2017-web.pdf. Letöltés ideje: 2019. december 13.

NBP (2015): Household Wealth and Debt in Poland - Pilot survey report 2014. 2015. https:// www.nbp.pl/en/publikacje/inne/bzgd/bzgd_2014_en.pdf. Letöltés ideje: 2019. december 13.

NBP (2017): Household Wealth and Debt in Poland - Report of 2016 survey. 2017. https:// www.nbp.pl/en/publikacje/inne/bzgd/bzgd_2016_en.pdf. Letöltés ideje: 2019. december 13. 
Perkins, D.W. (2019): The Potential Decline of Cash Usage and Related Implications. CRS Reports, May. https://crsreports.congress.gov/product/pdf/R/R45716. Letöltés ideje: 2019. szeptember 13.

Politronacci, E. - Ninlias, E. - Palazzeschi, E. - Torre, G. (2017): The demand for cash in France: Review of evidence. Előadás: International Cash Conference 2017, Mainau, április 25-27. https://www.bundesbank.de/resource/blob/634956/\%20906da37dde344bf1a77dd4ca717a4bc0/mL/2017-06-19-politronacci-data.pdf . Letöltés ideje: 2019. szeptember 13.

Politronacci, E. - Moret, A. - Bounie, D. - Francois, A. (2018): Use of cash in France: The payment method of choice for low-value purchases. Banque de France Bulletin, No. 220/2, December.

Reserve Bank of India (2017): Annual Report 2016-2017. https://rbidocs.rbi.org.in/rdocs/ AnnualReport/PDFs/RBIAR201617_FE1DA2F97D61249B1B21C4EA66250841F.PDF. Letöltés ideje: 2019. szeptember 13.

Rogoff, K. (2016): The Curse of Cash. Princeton University Press, Princeton, NJ, USA. https://doi.org/10.1515/9781400883219

Schweizerische Nationalbank (2018): Survey on payment methods 2017. https://www.snb.ch/ en/mmr/reference/paytrans_survey_report_2017/source/paytrans_survey_report_2017. en.pdf. Letöltés ideje: 2019. szeptember 13.

Seitz, F. - Reimers, H.-E. - Schneider, F. (2018): Cash in Circulation and the Shadow Economy: An Empirical Investigation for Euro Area Countries and Beyond. CESifo Working Papers 7143 , July.

Shirai, S. - Sugandi, E. A. (2019): Growing Global Demand for Cash. International Business Research, Vol. 12., No. 12. https://doi.org/10.5539/ibr.v12n12p74

Sisak Balázs (2011): What drives cash demand? Transactional and residual cash demand in selected countries. MNB Working Papers 2011/10.

Skingsley, C. (2018): Considerations for a cashless future. Előadás: SNS Finance Panel, Stockholm, 2018. november 22. https://www.riksbank.se/globalassets/media/tal/engelska/ skingsley/2018/skingsley_considerations-for-a-cashless-future.pdf. Letöltés ideje: 2019. szeptember 13.

Smestad, V.G. (2017): Danish households opt out of cash payments. Danmarks Nationalbank Analysis No. 24, December.

Söderberg, G. (2018): What is money and what type of money would an e-krona be? Sveriges Riksbank Economic Review, 2018:3, pp. 17-28. 
Stavins, J. (2018): Consumer preferences for payment methods: Role of discounts and surcharges. Journal of Banking \& Finance, 94(June): 35-53. https://doi.org/10.1016/j. jbankfin.2018.06.013

Sumner, S.B. (1990): The transactions and hoarding demand for currency. Quarterly Review of Economics and Business, 30(March): 75-89.

Végső Tamás - Belházyné Illés Ágnes - Bódi-Schubert Anikó (2018): Készpénz vagy kártya? A magyar lakosság fizetési szokásainak feltáró elemzése. Pénzügyi Szemle, 63(4): 455-479.

Wright, R. - Tekin, E. - Topalli, V. - McClellan, C. - Dickinson, T. - Rosenfeld, R. (2017): Less Cash, Less Crime: Evidence from the Electronic Benefit Transfer Program. NBER Working Paper No. 19996, March. https://doi.org/10.1086/693745

Zhang, L. - Brooks, R. - Ding, D. - Ding, H. - He, H. - Lu, J. - Mano, R. (2018): China's High Savings: Drivers, Prospects, and Policies. IMF Working Paper 18/277, December. https://doi.org/10.5089/9781484388778.001 